Supplement of Biogeosciences, 14, 5171-5188, 2017

https://doi.org/10.5194/bg-14-5171-2017-supplement

(C) Author(s) 2017. This work is distributed under

the Creative Commons Attribution 4.0 License.

(c) (1)

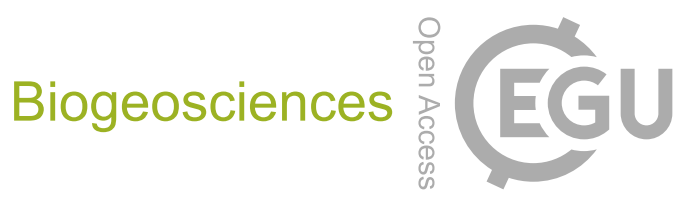

Supplement of

\title{
Ferrihydrite-associated organic matter (OM) stimulates reduction by Shewanella oneidensis MR-1 and a complex microbial consortia
}

Rebecca Elizabeth Cooper et al.

Correspondence to: Kirsten Küsel (kirsten.kuesel@uni-jena.de)

The copyright of individual parts of the supplement might differ from the CC BY 4.0 License. 

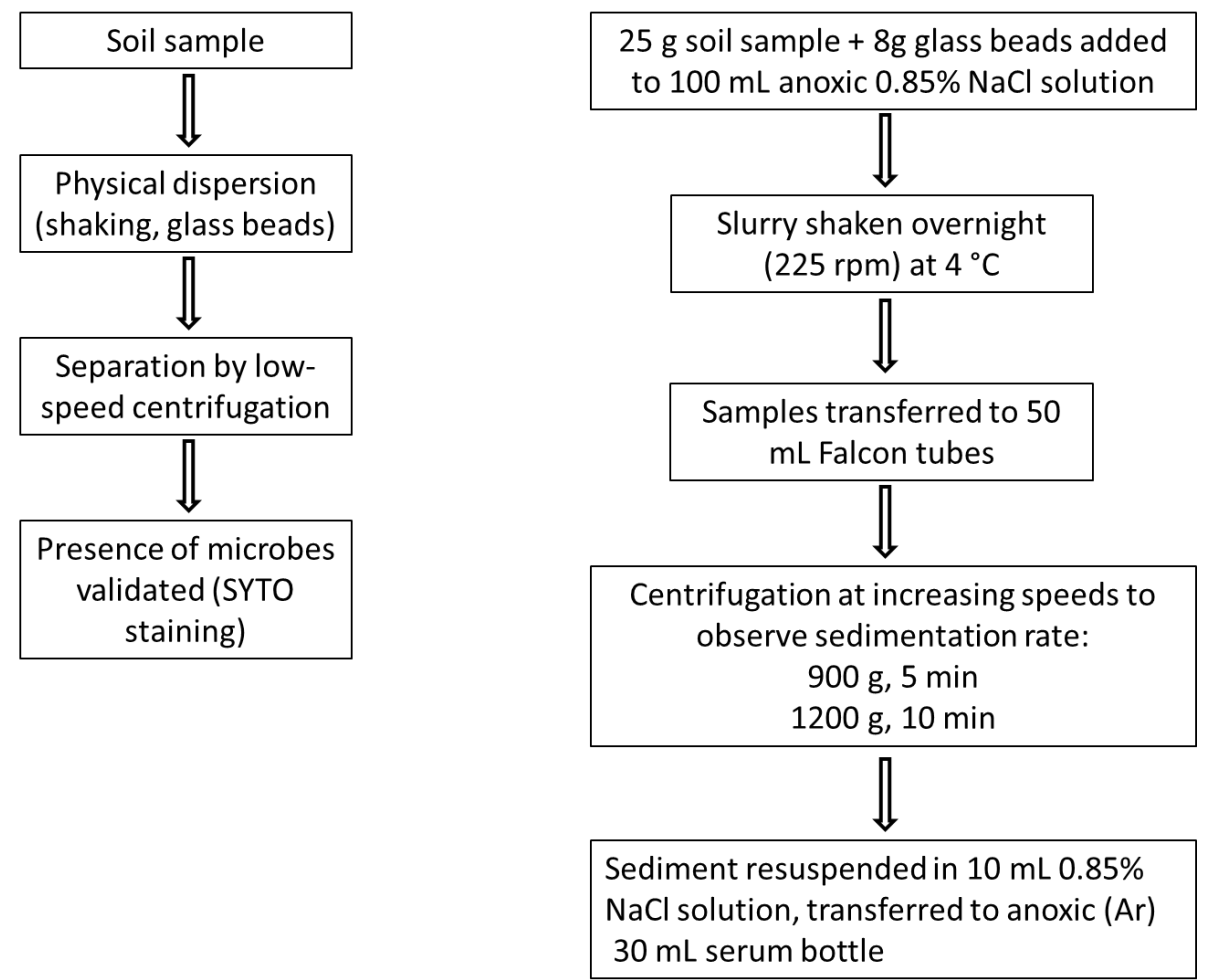

Supplemental Figure 1. Extraction of microbial community from peat cores. (A) Generalized flow chart for the extraction of bacteria from peat soil samples obtained from the Schlöppnerbrunnen fen (see text for details). (B) Detailed flow chart for the extraction of bacteria from peat soil samples obtained from the Schlöppnerbrunnen fen (see text for details). 